\title{
George Sand, Jacques
}

\section{Lise Sabourin}

\section{(2) OpenEdition}

\section{Journals}

\section{Édition électronique}

URL : https://journals.openedition.org/studifrancesi/26571

DOI : 10.4000/studifrancesi.26571

ISSN : 2427-5856

\section{Éditeur}

Rosenberg \& Sellier

\section{Édition imprimée}

Date de publication : 1 avril 2007

Pagination : 198

ISSN : 0039-2944

\section{Référence électronique}

Lise Sabourin, « George Sand, Jacques », Studi Francesi [En ligne], 151 (LI | I) | 2007, mis en ligne le 30 novembre 2015, consulté le 23 novembre 2021. URL : http://journals.openedition.org/studifrancesi/ 26571 ; DOI : https://doi.org/10.4000/studifrancesi.26571

Ce document a été généré automatiquement le 23 novembre 2021.

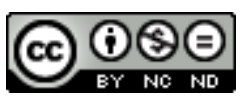

Studi Francesi è distribuita con Licenza Creative Commons Attribuzione - Non commerciale - Non opere derivate 4.0 Internazionale. 


\title{
George Sand, Jacques
}

\author{
Lise Sabourin
}

\section{RÉFÉRENCE}

GEORGE SAND, Jacques, présentation et bibliographie de David A. POWELL, Genève, Slatkine Érudition, 2006, pp. 409.

1 Ce premier roman au titre masculin, paru en 1834, juste avant André, a valu le scandale à George Sand, beaucoup s'étant complu à rechercher dans son héros éponyme l'ombre de Musset, tandis que les critiques contemporains se sont déchaînés sur ses revendications sociales: égalité des sexes, amour libre et statut du mariage, place des enfants dans les responsabilités du couple.

Dans sa présentation (pp. 7-27), David A. Powell, de l'Hofstra University de New York, rappelle l'appréciation romanesque négative de Balzac, la critique morale sur le dénouement de Janin, le point de vue plus mitigé d'Henry James, le rapprochement par Nerval avec Les Affinités électives. Puis il étudie le dramatis personae de l'intrigue en trois temps, des fiançailles de Fernande et Jacques à leur mariage et à l'épilogue de leurs destins. D'autres couples aident à constituer la chaîne narrative, sans oblitérer pour autant le devenir littéraire des héros dans la pensée de Sand qui revient en une «apocryphe résurrection» dans Le Diable aux champs, Monsieur Sylvestre, Valvèdre et Le Dernier Amour sur les issues possibles de la situation décrite dans Jacques. Articulation entre amour, amitié et mariage, exploration des tentations d'inceste et de suicide, ce roman constitue aussi une avancée par rapport à Rousseau, Mmes de Graffigny ou de Charrière dans le maniement de l'épistolarité dont George Sand réexploitera les apports dans Le Secrétaire intime ou Le Marquis de Villemer. 